\title{
The Impact of Entrepreneurial Orientation on Business Performance: A Study of SMEs in Horticulture Sector
}

\author{
Sameer Ahmad Shalla \\ Assistant Professor, School of Business Studies, \\ Islamic University of Science \& Technology, Awantipora, J\&K
}

\begin{abstract}
The present study aims to examine the impact of entrepreneurial orientation on business performance of 30 horticulture related firms in Kashmir. The entrepreneurial orientation is measured by five dimensions identified from the literature on the subject and financial performance; a dependent variable is treated as a measurement for business performance. The correlation and regression analysis was used to analyze the relationship between entrepreneurial orientation and business performance of the sampled firms.
\end{abstract}

Keywords: Entrepreneurial,

Orientation, Performance, horticulture, regression

\section{Introduction}

Entrepreneurial orientation is a very important pillar of decision making in the current complex and dynamic business environment. The success in terms of better business performance and competitive advantage depends on the way decision making is done in an enterprise (Azlin et al., 2013). The businesses seek new opportunities by launching new products or services (innovation), by being proactive, risk taking which drives growth and profitability of an enterprise (Muenjohn and Armstrong, 2008). The present study has adopted the five dimensions of entrepreneurial orientation (EO) which was developed by Lumpkin and Dess (1996). These dimensions of EO have been studied in different contexts by various scholars such as (Lim \& Pathak, 2011) \& (Li, Huang and Tsai, 2009).
As indicated by Chen, Du and Chen (2011), EO is important to the growth of a company and also to the growth of the economy of a country. In fact, few scholars agreed that EO is a significant contributor to a firm's success and contributes to a healthier business performance (Mahmood and Hanafi, 2013; Zainol and Ayadurai, 2011). In fact, many studies have appreciated the importance of entrepreneurial opportunity to the firms performance (Schindehutte, Morris and Kocak, 2008; Tajeddini, 2010; Haq and Chauhan, 2011; Fauzul, Takenouchi and Yukiko, 2010; Wang, 2008). As has been argued by Rodrigues and Raposo (2011) and Rodrigues (2005), firms that have a high EO have a superior performance where the market share showed improvements and the number of new products, services and processes has shown some growth. All firms need to be entrepreneurial in order to survive and successfully compete, especially within the fast-changing industries (Teece, 2007). As mentioned by Lindelof \& Lofsten (2006), rapid technological progress reinforces the competitive pressures and creates a rich pool of technological opportunities that encourage entrepreneurial behavior of firms. The present study has selected 30 SMEs from horticulture sector in Kashmir and has attempted to analyze their business performance based on entrepreneurial orientation of these firms.

\section{Literature Review}

Avlonitis and Salavou (2007) define entrepreneurial orientation as an organizational phenomenon that 
reflects a managerial capability by which firms embark on proactive and aggressive initiatives to alter the competitive situation to their advantage. Lumpkin and Dess (1996) developed five dimensions that characterize the EO of a firm: innovativeness, proactiveness, risk taking, competitive aggressiveness and autonomy. Innovativeness reflects the tendency to engage in and support new ideas, novelty, experimentation and creative processes resulting in something new. Pro-activeness reflects a firm's actions in exploiting and anticipating emerging opportunities by developing and introducing as well as making improvements towards a product or a service (Lumpkin and Dess, 1996). Risk-taking represents the willingness to commit resources to undergo activities and projects which resulted in uncertainty of the outcomes (Lumpkin and Dess, 1996). Risk-taking is defined as the extent to which a firm is willing to make large and risky commitments (Covin and Slevin, 1991). Competitive aggressiveness is the intensity of the firm's to improve their position to outdo and overtake their competitors in the market (Lumpkin and Dess, 1996). It is characterized by a strong offensive posture directed at overcoming competitors and may be quite reactive as when a firm aggressively enters a market that a rival has identified (Lumpkin and Dess, 1997). Autonomy refers to an independent action of an individual or teams in ensuring ideas and concepts are being carried out till completion (Lumpkin and Dess, 1996). Autonomy gives employees the chance to perform effectively by being independent, self-directed, creative and teleological. As suggested by Knight (2000), majority of earlier studies have adopted self-reported measures to gather business performance data which have proven to be reliable. Moreover, Yang (2008) asserts that public information provided by small and medium enterprises is unreliable as most of the firms are privately held and they have no legal obligation to disclose information. According to Wiklund (1999), financial performance is a common performance measurement. The researcher has therefore relied on financial performance as a measurement of business performance. The relationship between EO and firm performance has become the main subject of interest in past literatures. According to Rauch, Wiklund, Lumpkin and Frese (2009), it is likely for firms adopting EO to perform better than companies that adopt conservative orientation. Initially, one could question the importance of EO for the success of enterprises. Thus, previous research studies have shown that entrepreneurial opportunity could significantly improve business performance (Covin and Slevin, 1991; Lumpkin and Dess, 1996; Wiklund and Shepherd, 2005; Covin and Slevin 1989; Lumpkin and Dess, 2001). There are various studies on EO and business performance that have reported positive results (Jantunen, Puumalainen, Saarenketo, and Kylaheiko, 2005; Chow, 2006; Coulthard, 2007; Wiklund, 1999; Wiklund and Shepherd, 2003, 2005; Zahra, 1991; Zahra and Covin, 1995; Madsen, 2007; Keh, Nguyen and Ng, 2007; Lee, Lee and Penning, 2001; Lumpkin and Dess, 1996). However, there is no doubt there are also studies that revealed that EO does not give positive results to business performance (Hart, 1992; Matsuno, Mentzer and Ozsomer, 2002; Morgan and Strong, 2003; Smart and Conant 1994).

\section{Objectives:}

a) To study the relationship between entrepreneurial orientation and financial performance of 30 horticulture related business firms in Kashmir.

\section{Hypotheses}

H01: Autonomy is not associated with profitability. H02: Pro-activeness is not related with profitability. H03: Innovativeness is not related with profitability. H04: Risk taking is not related with profitability. H05: Competitive aggressiveness is not associated with business performance.

\section{Methodology}

The present study has adopted a descriptive cum exploratory methodology for achieving the objective of the current study. The data was collected using a questionnaire based on a 5-point Likert Scale. The questionnaire was distributed among top 50 firms in Sopore fruit Mandi in Baramulla district. However, only 30 firms responded to the survey questionnaire resulting in $60 \%$ response rate. According to Roscoe's (1975) rule of thumb, a sample size between 30 and 500 is sufficient. Since, small and medium firms are run by few individuals with centralized authority, therefore, they are the most informed individuals about the firms' overall operational activities (Yang, 2008). The entrepreneurial orientation (OE): an independent variable (IV) was measured by 5 identified dimensions from the literature and profitability was used a measurement for business performance which is a dependent variable (DV). The data was analyzed using both descriptive and 
International Journal of Trend in Scientific Research and Development (IJTSRD) ISSN: 2456-6470

inferential statistical tools for drawing accurate inference and interpretation. The SPSS 20.0 was used for data analysis.

\section{Results \& Analysis}

The sample consists of 30 horticulture related businesses. All the respondents are from small \& medium size enterprises. Since, Sopore is known as Apple town with heavy concentration of fruit growers and one of the biggest fruit markets in India. Therefore, all the firms have been selected from the Sopore fruit mandi.

Table 1.1: Sample Profile

\begin{tabular}{|c|c|}
\hline \multicolumn{1}{|c|}{ Table 1.1: Sample Profile } \\
\hline Sector & Horticulture \\
\hline Company Size & Small \\
\hline Location & Sopore, Kashmir \\
\hline $\mathrm{N}$ & 30 \\
\hline
\end{tabular}

\section{Source: Field Survey}

The reliability test was conducted for ascertaining the internal consistency of the dependent and independent variables. The entrepreneurial orientation and business performance have a Cronbach Alpha values of more than 0.68 which is acceptable according to Hair and Page (2008). The results are reported in table 1.2 .

Table 1.2 Results of Reliability Test

\begin{tabular}{|l|c|c|}
\hline Measure & Items & $\begin{array}{c}\text { Cronbach } \\
\text { Aplha }\end{array}$ \\
\hline Innovativeness & 6 & .73 \\
\hline Pro-activeness & 5 & .71 \\
\hline Autonomy & 6 & .72 \\
\hline Risk-taking & 8 & .70 \\
\hline $\begin{array}{l}\text { Competitive } \\
\text { aggressiveness }\end{array}$ & 7 & .68 \\
\hline $\begin{array}{l}\text { Business } \\
\text { Performance }\end{array}$ & 8 & .71 \\
\hline
\end{tabular}

Table 1.3 depicts the correlation analysis between the five dimensions of EO and business performance. It was observed that the Pearson correlation between EO \& Innovativeness is significant at .567; EO \& Proactiveness is significant at .452 , EO \& Autonomy at .432 , OE \& Risk-taking at $.390, \mathrm{OE}$ and Competitive aggressiveness at .379 .

\begin{tabular}{|l|l|}
\hline OE & Business Performance (BP) \\
\hline Innovativeness & $.567 * *$ \\
\hline Pro-activeness & $.452 * *$ \\
\hline Autonomy & $.432 * *$ \\
\hline Risk-taking & $.390 * *$ \\
\hline Competitive aggressiveness & $.379 * *$ \\
\hline \multicolumn{2}{|c|}{$* *$ Correlation is significant at the 0.01 level (2-tailed). }
\end{tabular}

After correlation analysis multiple regression was conducted to investigate the relationship between OE and BP. The results of the regression analysis was presented in table 1.4. 
Table 1.4: Regression Model Summary

\begin{tabular}{|l|l|l|l|l|}
\hline Model & $\mathbf{R}$ & R Square & $\begin{array}{l}\text { Adjusted R } \\
\text { Square }\end{array}$ & $\begin{array}{l}\text { Std. Error of the } \\
\text { Estimate }\end{array}$ \\
\hline EO & $.621^{\mathrm{a}}$ & .412 & .255 & 5.71 \\
\hline
\end{tabular}

a. Predictors: (constant), IN, RT, PA, AUT, CA

The $\mathrm{R}$ square value is .412 which indicates that $41.20 \%$ of variance in business performance (BP) is explained by five dimensions of entrepreneurial orientation $(\mathrm{OE})$.

\section{Table 1.5: Coefficients}

\begin{tabular}{|l|c|c|c|c|c|}
\hline \multirow{2}{*}{ Model } & \multicolumn{2}{|c|}{$\begin{array}{c}\text { Unstandardized } \\
\text { Coefficients }\end{array}$} & $\begin{array}{c}\text { Standardized } \\
\text { Coefficients }\end{array}$ & \multirow{2}{*}{ Sig. } \\
\cline { 2 - 5 } & $\mathbf{B}$ & Std. Error & Beta & & \\
\hline Innovativeness & .790 & .330 & .270 & 2.16 & .000 \\
\hline Pro-activeness & .316 & .537 & .268 & 1.23 & .000 \\
\hline Autonomy & .223 & .340 & .140 & 1.43 & .000 \\
\hline Risk-taking & .482 & .344 & .132 & 1.67 & .000 \\
\hline $\begin{array}{l}\text { Competitive } \\
\text { aggressiveness }\end{array}$ & 1.21 & .247 & .129 & 2.1 & .000 \\
\hline
\end{tabular}

a. DV: Business Performance of Horticulture related Firms

The coefficients in the above table 1.5 show which among the five independent variables of EO influences most the variance in business performance. The column Beta under Standardized Coefficients shows that the highest number in the beta is .270 for innovativeness which is significant at the .001. Proactiveness was ranked second with beta 0.268 at the significant .001 followed by Autonomy dimension with beta 0.140 at the significant .001 , risk-taking with beta .132 and Competitive aggressiveness with beta .129 all dimensions are significant at the level 0.05. All five dimensions of EO significantly affect the business performance of horticulture related firms. Hence, Hypothesis 1, 2, 3, 4 and 5 are rejected.

\section{Conclusion}

It was observed from correlation analysis that there is a small to medium association between EO and business performance. The study also revealed that all the five dimensions of Lumpkin and Dess's (1996) EO significantly effect the business performance of 30 selected horticulture related business firms. The study is limited to the perceptions of the performance $\&$ EO of only 30 companies in horticulture sector of
$\mathrm{J} \& \mathrm{~K}$. Therefore, in view of the enormous significance of horticulture sector for the development of economy of J\&K further broad based research studies with more objective performance measurements should be adopted. Which could better determine the behavior of business performance and entrepreneurial orientation in horticulture sector.

\section{REFERENCES}

1) Avlontis, G.J. and Salavou, H.E. (2007), "Entrepreneurial orientation of SMEs, product innovativeness, and performance", Journal of Business Research, Vol. 60 (5), 566-75. Biotechnology Information Centre, Malaysia. (2001). Retrieved 23 October 2012, from http://www.bic.org.my/index.html.

2) Chen, G., Du, H., and Chen, Y. (2011). Research on Entrepreneurial Orientation and Entrepreneurial Behavior: An Empirical Study. In Management and Service Science (MASS), 2011 International Conference on (pp. 1-3). IEEE. 
3) Chow, I.H. (2006). The Relationship between Entrepreneurial Orientation and Firm Performance in China. S A.M. Advanced Management Journal, $71(3), 11-20$.

4) Coulthard, M. (2007). The Role of Entrepreneurial Orientation on Firm Performance and the Potential Influence of Relational Dynamism. Journal of Global Business and Technology. 3 (1), 29-39.

5) Covin, J.G. and Slevin, D.P. (1989). Strategic Management of Small Firms in Hostile and Benign Environments. Strategic Management Journal. 10 (1), 75-87.

6) Covin, J.G. and Slevin, D.P. (1991). A Conceptual Model of Entrepreneurship as Firm Behavior. Entrepreneurship Theory and Practice. 16, 7- 25.

7) Creswell, J.W. (2005). Educational Research: Planning, Conducting, and Evaluating Quantitative and Qualitative Research (2nd ed.). Upper Saddle River, N.J.: Pearson Education.

8) Fauzul, M. F., Takenouchi, H., and Yukiko, T. (2010). entrepreneurial orientation and Business performance of small and medium scale enterprises in Sri Lanka. Asian Social Science, 6 (3), 34-46.

9) Hair, J. F., Money, A., Page, M. and Samouel, P. (2007). Research Methods for Business. England: John Wiley \& Sons Ltd.

10) Li, S., Ragu-Nathan, B., Ragu-Nathan, T. S., and Subba Rao, S. (2006). The impact of supply chain management practices on competitive advantage and organizational performance. Omega The International Journal of Management Science. 34 (2), 107-124.

11) Lindelöf, P. and Löfsten, H. (2006), Environmental Hostility and Firm Behavior - An Empirical Examination of New Technology-based Firms on Science Parks. Journal of Small Business Management. 44 (3), 386-406.

12) Lumpkin, G. \& Dess, G. (1997). Proactiveness Versus Competitive Aggressiveness: Teasing Apart Key Dimensions of an Entrepreneurial Orientation. In P. D. Reynolds, W. D. Bygrave, N. M. Carter, P. Davidsson, W. B. Gartner, C. M. Mason \& P. McDougall (Eds.), Frontiers of
Entrepreneurship Research. Babson Park, MA: Babson College.

13) Lumpkin, G.T. and Dess, G.G (2001). Linking Two Dimensions of EO to Firm Performance: The Moderating Role of Environment and Industry Life Cycle. Journal Business Venturing. 16 (5), 429-451.

14) Muenjohn, N. and Armstrong, A. (2008). Evaluating the Structural Validity of the Multifactor Leadership Questionnaire (MLQ), Capturing the Leadership Factors of Transformational-Transactional Leadership. Contemporary Management Research. 4 (1): 3-14.

1) Walter, A., Auer, M. and Ritter, T. (2006). The Impact of Network Capabilities and Entrepreneurial Orientation on University Spin-off Performance. Journal of Business Venturing. 21, 541-567. 